\title{
JEASP
}

Journal of English for Academic and Specific Purposes

Volume 4 Number 1, June, 2021

\section{PROMOTING WILLINGNESS TO COMMUNICATE IN IMPROVING STUDENTS' SECOND LANGUAGE ACQUISITION THROUGH LIVEWORKSHEETS.COM}

\author{
Nissa Ilma Mukti ${ }^{1}$ \\ (nissailmamukti@gmail.com)
}

Rochmawati 2 ,

(rahma.mlg@gmailcom)

Alfiah Nur Senta ${ }^{3}$,

(alfiabnursenta@gmail.com)

Leo Candra Wahyu Utami ${ }^{4}$, (leocandrawahyn@gmail.com)

\section{Zulvy Alivia Hanim 5 \\ (zulfyalivia@gmail.com)}

Pusat Pengembangan Bahasa Inggris

Universitas Islam Negeri Maulana Malik Ibrahim Malang ${ }^{12345}$

\begin{tabular}{l} 
ARTICLE \\
\hline Keywords: \\
liveworksheets, \\
willingness to \\
communicate, \\
second language \\
acquisition
\end{tabular}

\section{ABSTRACT}

This research investigates on the use of online platform media learning, namely liveworksheets.com to facilitate students' willingness to communicate and acquire their second language in an online classroom. This study is considered essential to be taken account to, as it correlates to the current situation, in which classes are conducted online. To gain the data, questionnaire were distributed to third semester students who are learning English as part of their course for a foreign and second language in Universitas Islam Negeri Maulana Malik Ibrahim Malang. By applying a mixed-method research design, the result of the study presents that there were four main factors affecting students' willingness to communicate when using liveworksheets.com. This includes learners' behavioral intention, interlocutors, motivations and their affective-cognitive skills. Moreover, it was also noted that liveworksheets.com was found to be quite beneficial in facilitating students to acquire their second language through the mentioned aspects. Hopefully, the result of the study may bring new insight and contribute to the online teaching learning process that takes place nowadays both for teachers and second language learners. 


\section{INTRODUCTION}

One of the major challenges faced by language learners to acquire a language is based on their unwillingness to communicate due to both external and internal factors. Willingness to Communicate or known as (WTC) is one of the communication frameworks that still interest second language researchers' attention until today (MacIntyre, Dorneyi, Clement and Noels, 1998). As noticed, due to the pandemics of COVID-19, where it is difficult for live interaction to occur, it is inevitable for students to practice and willing to use their English speaking skills in a formal tuition. Therefore, the teaching and learning process is suggested to be conducted online. Fortunately, online learning has offered variety of platforms to support the teaching and learning process, one of which is liveworksheets.com.

Liveworksheets.com allows teachers to create worksheet which encourage students' speaking ability in a very effective and enjoyable way. This, in turn, will enhance students' willingness to communicate and help them acquire their English speaking skills (Yashima, 2002). As stated by Lightbrown and Spada (2001), when learners acquire language, they need to be in a readiness and supportive state, which can be facilitated by using the suggested platform and induced by the lecturers. Moreover, the process of acquiring a language may also be affected by learners' personal characteristics, motivation, self-confidence, affective, language learning aptitude, social and individual factors which may be found and modified through the learner's WTC (MacIntyre, Dorneyi, Clement and Noels, 1998). This is also shown in the heuristic model below (see Figure 1.1)

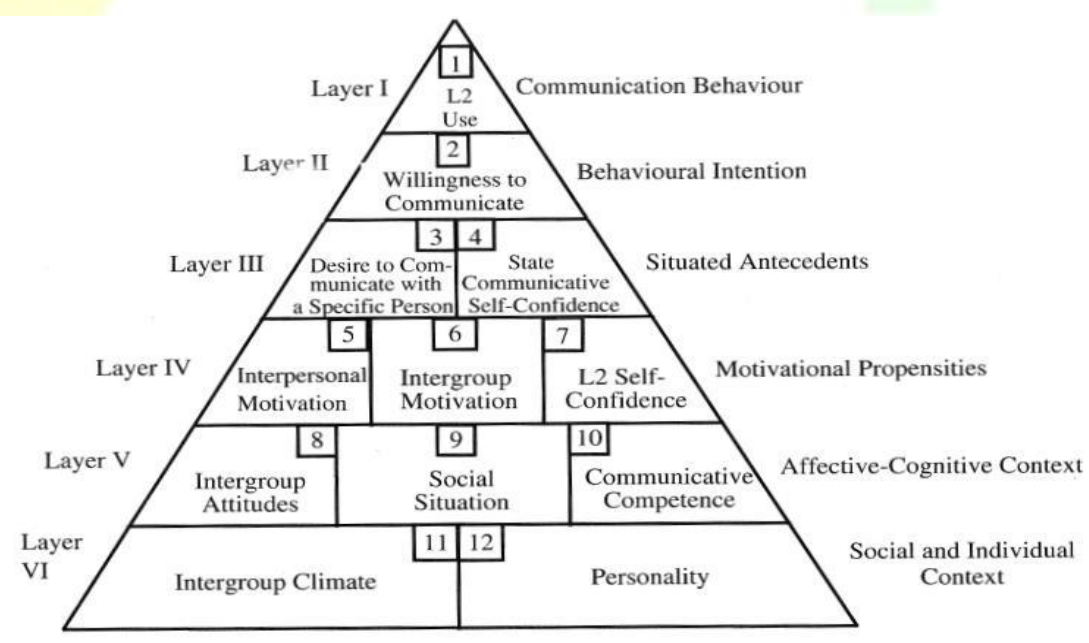

Figure 1.1

The six layers models of hierarchy depicts the least features inducing a students' WTC (shown in the bottom tier), right until the most item prompting learners' WTC (presented in the top layer). The six 


\section{JEASP}

Journal of English for Academic and Specific Purposes

Volume 4 Number 1, June, 2021

layers are grouped into two main phase, namely "situational specific influences" (layer I-III) and "stable and enduring influences" (layer IV-VI) factors (McIntyre, 1998). The ability of language learner to communicate using English is found in the first and second layer (communication and behavioural interaction). In this case, students' WTC will be seen from the online/ daring context. In the next tier, the situated antecedents consist of the learners' WTC which is determined by who they are speaking to and state communicative self-confidence which is affected by the state perceived confidence as well as anxiety McIntyre (1998). This has also been proven by previous studies such as Pawlak and Wiertelak (2015); Tavakoli and Davoudi (2015), Öz, Demirezen and Pourfeiz (2015) who have argued that the role of interlocutor and the students' state of confidence greatly affects their willingness to communicate. In the research proposal, this may be seen from how learners try to speak with their teachers through the worksheet.

Consequently, the motivational propensities layer is classified into intergroup motivation, referring to how the learners' motivation is affecting them when adjusting to a particular group of people. The research investigating this issue includes Ghanbarpour (2016); Ghani and Azhar (2017) who have established that there is a positive connection between motivation and anxiety towards WTC in the second language context. Therefore, the correlation towards the two factors may become the drawbacks to the second language willingness to communicate specifically in Indonesia. Subsequently, the affective-cognitive context includes three factors, including social situation, intergroup attitudes, and communicative competence. These factors have been suggested as the least issues influencing WTC (Zarrinabadi and Tanbakkooei, 2016). While intergroup attitudes covers the second language WTC to language acquisition, social situation is closely related to the learners' confidence and communicative competence. This may be based on the theme, function or purpose, and the interlocutor's ability to use English communicatively (McIntyre et al., 1998). Lastly, social and individual context (the lowest level) includes the intergroup climates and personality. Intergroup climates feature the learners' preference towards attribute to learner's perspective towards the public, while personality includes the items which implicitly affects learners' willingness to communicate (McIntyre et al., 1998).

Based on the above, rationale, this study aims to answer the following issues. First, it aims to find out how liveworksheets.com facilitates students to improve their willingness to communicate and to acquire their English language. Second, what WTC aspects that construct students' second language acquisition are. Hopefully, this research may also contribute to the pedagogical aspects, specifically in the teaching and learning process 
JEASP

Journal of English for Academic and Specific Purposes

Volume 4 Number 1, June, 2021

\section{METHOD}

To examine how to encourage student's willingness to communicate to improve their second language acquisition through online teaching and learning using liveworksheets.com platform, the researchers implement a quantitative-qualitative mix method design (Ivankova \& Geer, 2015). The quantitative design is implemented to get the data from survey by giving questionnaire to the participants. The qualitative design is implemented to examine the participants' videos by giving feedback. It also implemented to describe the phenomena of second language acquisition which occur during teaching and learning process.

This study was conducted in UIN Maulana Malik Ibrahim Malang, Pharmacy Department, Intensive English Class which have been assessed by the English Language Center. The participants consist of approximately 50-100 students of Pharmacy Department of UIN Maulana Malik Ibrahim Malang. They are the third semester students, (about 17- 20 years old) who are taking Intensive English Class online and using liveworksheet.com as one of their media to enhance their speaking ability. The participants were given questionnaire which concern on how online classes affects their willingness to communicate, and how the online platform (liveworksheets.com) help them improve their willingness to communicate in acquiring English language.

For quantitative data, the researchers obtained the data from the results of questionnaire. Close-ended and Open-ended questionnaire were utilized in this study. Close-ended questionnaire contain 3 parts to scale and evaluate the effect of liveworksheet in improving student's willingness to communicate. Open ended questionnaire was used as in the researcher wants to know and examine the personal opinion about the use of liveworksheet in student's speaking activity. The questionnaires were distributed to the students who have done the test in liveworksheet that the researchers given during the class in order to answer the research questions of this study.

This study involved two data collection procedures. In the first, the researchers requested students to self-practice in liveworksheet.com. The researchers provided a video tutorial explaining how to use liveworksheet.com, so that it can be used correctly. After understanding the instruction, the students took turn completing the task by recording their voice based on the question items provided in www.liveworksheets.com. Then, the respondents were asked to fulfill the questionnaire, which consists of the items that supports to find out student's experience after using liveworksheet.com and to know its relation with the increasing student's desire to speak English. Moreover, to ensure the validity, both quantitative and qualitative data were reviewed by experts and went through the validity checks as purposes by Phakiti (2015) for quantitative data and Halliday (2015) for qualitative data. 


\section{JEASP}

Journal of English for Academic and Specific Purposes

Volume 4 Number 1, June, 2021

\section{Reliability Statistics}

Cronbach's

\begin{tabular}{r|r}
\multicolumn{1}{c|}{ Alpha } & N of Items \\
\hline .870 & 34 \\
\hline
\end{tabular}

Figure 3.1

Following the quantitative-qualitative mixed method design, this study analyzed quantitative and qualitative results correspondingly, following Ivankova and Geer's (2015) mixed method analysis. Quantitative analysis is used to answer research question 2, while qualitative analysis is used to answer research question 1.

\section{Quantitative Data Analysis}

Firstly, the data were checked and organized to reassure that the participants' personal information are correct and that all items in the questionnaire are accurately answered. The incomplete data were removed from the analysis, while the accurate data were given an ID and further used. From this process, it was noted that from about 250 data, only 100 data were eligible to be used, as some of the questionnaire items in the data were not answered. Then, these data were organized and coded into scales, nominal data and ordinal data to be further input and investigated using SPSS. Consequently, descriptive analysis were performed to found out the data demographic including frequencies, means, and standard deviations. Based on the descriptive analysis, the score shown was about 4.00, indicating that the data were normally distributed. Moreover, the SD's score was also within the range of \pm 1 , indicating that the data is homogenous and well-provided (see table 2).

\section{Descriptive Statistics}

\begin{tabular}{lr|r|r|r|r} 
& \multicolumn{1}{c|}{$\begin{array}{c}\text { Minim } \\
\text { um }\end{array}$} & $\begin{array}{c}\text { Maxim } \\
\text { um }\end{array}$ & Mean & $\begin{array}{c}\text { Std. } \\
\text { Deviation }\end{array}$ \\
\hline Q1 & 100 & 1 & 5 & 3.90 & .804 \\
\hline Q2 & 100 & 3 & 5 & 3.77 & .979 \\
\hline Q3 & 100 & 3 & 5 & 3.88 & .842 \\
\hline Q4 & 100 & 2 & 5 & 3.73 & .779 \\
\hline Q5 & 100 & 2 & 5 & 3.73 & .827 \\
\hline Q6 & 100 & 3 & 5 & 4.17 & .820 \\
\hline
\end{tabular}


JEASP

Journal of English for Academic and Specific Purposes

Volume 4 Number 1, June, 2021

Figure 3.2

Once the data is set to be investigated, the questionnaire items are grouped into the aspects affecting students' WTC, then tested its reliability, which is also above 0.70 . The aspects include:

1. Social and individual context that consist of Personality \& intergroup climate aspect

2. Affective-Cognitive Context that consist of communicative competence, social situation \& intergroup attitude aspect

3. Motivational Propensities that consist of interpersonal motivation, intergroup motivation \& selfconfident aspect

4. Situated Antecedents that consist of state communication self-confidence \& desire to communicate with specific person.

\section{Qualitative Data Analysis}

In line with Holliday (2015), the qualitative data is analyzed classically, which includes:

1. Coding: Responses are classified into several points

2. Determining themes: The points are coded and grouped with a certain theme, including the aspects of W'TC.

3. Going back to the data: The researcher reevaluated the data

\section{FINDINGS AND DISCUSSION}

The results of the study were based on the research questions, which includes how liveworksheets.com was able to facilitate students' willingness to communicate and acquire their second language, as well as the aspects affecting it. These will be elaborated below.

\section{Liveworksheets in Facilitating Students to Improve their Willingness to Communicate}

The questionnaire responses indicate that all aspects including desire to communicate with a specific person, state communicative self-confidence, L2 self-confidence, and personality affects' learners' willingness to communicate. However, there were four dominating aspects among these, which are L2 self-confidence, situated antecedents, motivations, communicate and personality.

\section{a) Self-Confidence}

In terms of self-confidence, most of the students in questionnaire response reveal that they feel confident when they speak English in liveworksheets.com, specifically in correlation to pronunciation. They suggested that they do not feel ashamed or afraid when they mispronounce 


\section{JEASP}

Journal of English for Academic and Specific Purposes

Volume 4 Number 1, June, 2021

the words. Moreover, students feel more relaxed and enjoy the time when they have to record their voices to pronounce the words. This is in accordance to the research result revealed by Clément, et.al (1998) that L2 self-confidence is related to the anxiety to communicate. Therefore, the students do not feel anxious when they use liveworksheets.com because they feel confident when they merely face the online platform to speak. This is also supported by the quantitative finding which shows that more than $50 \%$ respondents agree with some questionnaire items related to behavioral intention, while more than $40 \%$ of the respondents intensely agree with some questionnaire items that answer how they deal with constructing communication through liveworksheets.com. (see Figure 4.1).

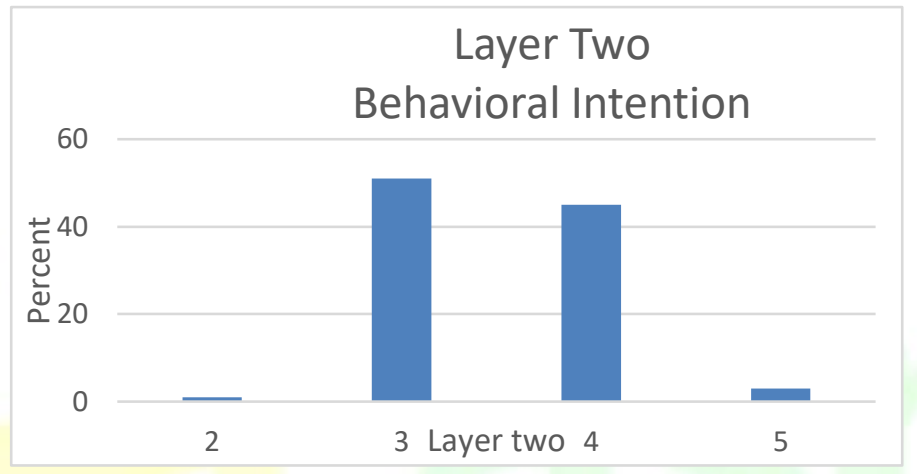

Figure 4.1

This shows that respondents are more comfortable to speak English through liveworksheets.com as it can boost their self-esteem to communicate in English while using liveworksheets.com. Ghanbarpour (2016) found that self-confidence significantly contribute in affecting WTC in second language context. The result of this study showed that their selfconfidence increased when the respondents as foreign language learners did the English test using platform liveworksheets.com, which is in line with the study conducted by Pramita (2012).

\section{b. Situated antecedents}




\section{JEASP}

Journal of English for Academic and Specific Purposes

Volume 4 Number 1, June, 2021

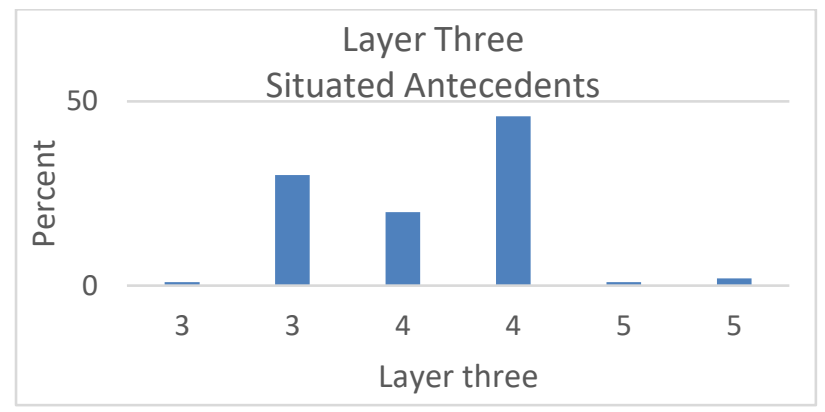

Figure 4.2

Situated antecedents closely relates to one's desire to communicate with a certain interlocutor and their self-perceived self-confidence. Results show that this aspect also significantly influence students' second language acquisition (30-50\%), as respondents mostly agree that their way of speaking closely relates to who they are speaking to (see point c. motivational propensities). In this study, students speak through a platform in which the interlocutors may be themselves or their teachers. By this, learners show less hesitation to communicate immediately to the interlocutor. In line with the previous findings about self-confidence, respondents will not be confident of their language competence when other people do not understand them. Yet, liveworksheets.com helps the foreign language learners to decrease the anxiety and enhance the language competence to prepare them for encountering such situation. This is in line with Zarinabadi and Addi (2011), and Damahdi (2014) whom suggested that their classroom environment has an influence on students' desire to communicate because there are supporting elements such as the presence of teachers who help train their speaking skills, friends, and other facilities that support and put pressure on students to learn and acquire language.

\section{c. Motivational propensities}

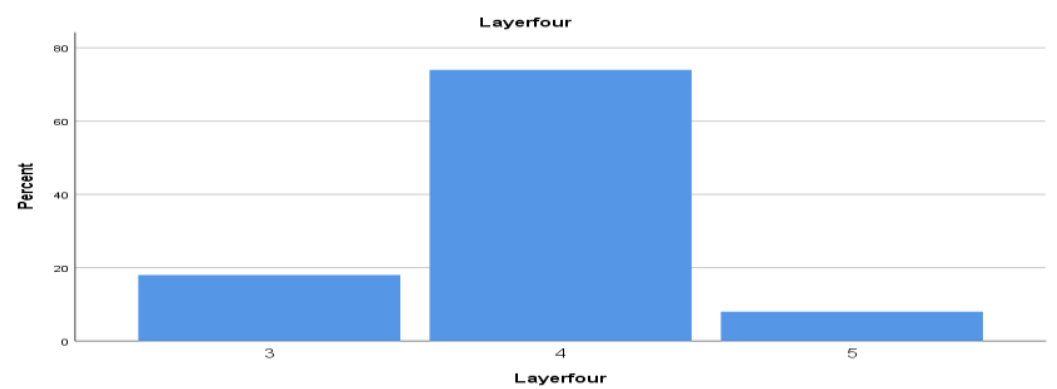

Figure 4.3 
JEASP

Journal of English for Academic and Specific Purposes

Volume 4 Number 1, June, 2021

Based on the graph, it can be seen that motivations, self-confidence, or also known as perceived competence and level of language anxiety, strongly influences students' willingness to communicate which is similar to Cao (2014). In correlation to goal, motivation is known as ones' ability to achieve goals that are either related to integrative or instrumental aspects. Noticeably, most students of Intensive English classes has emphasized that their underlying reason of being motivated speak in the targeted language is due to their interest of the given topics. They have argued that the familiar topics suggested to the students have driven their motivation further to use English as accurately as possible for discussion. This is also proven by the fact that students tend to answer the questions enthusiastically in correlation to the familiar topics given in liveworksheets.com, such as describing about someone or talking about the most memorable moment they have.

Another factor that drives their motivation to speak English is due to their willingness to communicate to native speakers. As Wood (2016) suggests, speaking with the native speaker of the target language may support learners to know how to speak English fluently and accurately. Although these students have not been given the chance to speak with native speakers, liveworkseets.com offers them a chance to learn autonomously about how to accurately produce the targeted language accurately in speaking.

As for the motivational factor that is caused by their surroundings, it was found that both their interpersonal and intergroup motivation aspects closely relates to their willingness to communicate. The ESL students agreed that by peer work or group discussion about a certain issue will reduce their anxiety and increase their self-confidence. Due to this, as also suggested by Ghani and Azhar (2017) students who have a low level of anxiety may have a high communication apprehension, self-esteem and perceived communicative competence. Interestingly, most of these answers came from students with low proficiency of English, which is contrasting to several findings like Ghanbarpour (2016). They have suggested that Second language learners' communicative competence may be reduced due to their inadequacy of English skills. Moreover, it has also been argued by them that the fear of losing face, negative experiences of English speaking or ones' beliefs about having to show respect and be passive in class may be the contributing factor to students' unwillingness to communicate.

Again, the cause to the different findings may be caused by the fact that these students are acquiring and speaking English using a platform, instead of being in a real-class situation. In another case, as mentioned earlier, these students may be discussing a familiar topic or that they have a strong intergroup or interpersonal motivation. Due to this, they may feel at ease and not feel any burden at all when having to speak in English, despite of their low proficiency. This aspect is in line with the 
JEASP

Journal of English for Academic and Specific Purposes

Volume 4 Number 1, June, 2021

affective-cognitive context, which will be deliberated below.

\section{d. Affective-cognitive context}

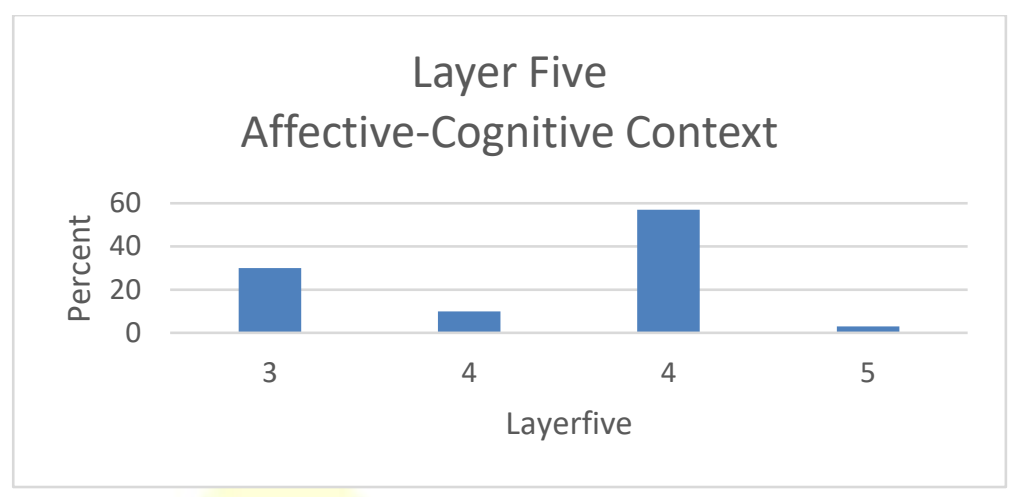

Figure 4.4

In order to investigate WTC aspects that construct students' second language acquisition, Affective - Cognitive Context from layer five have significant correlation with the way students being willing to communicate. In this case, Communicative competence as one of Affective Cognitive Context aspect strongly affected L2 learners to speak. They tend to communicate when they have good readiness on their language skills. Canale and Swain (1980) proposed that Grammatical competence and sociolinguistics competence are two fundamental aspects that built communicative competence. From this study, the researchers found correlation between communicative competence and the desire to communicate. More than $50 \%$ students frequently reported that they enjoyed and wanted speaking because they satisfied with their speaking ability.

This result in line with Pattapong (2010), asserted that students with lack of grammatical competence experienced difficulty in communicating and understanding the message that made them nervous and felt hesitate doing communication. He also stated that this situation influenced by self-concept, in which comparing their English competency with their selfsatisfaction or comparing with other people's performance. Therefore, having good level of proficiency mainly in speaking skill influence student's willingness to communicate. Yet, although communicative competence and social situation may help students to acquire their English skills, in this study however, students' satisfaction of linguistic competence may not only be caused by their high proficiency of English, but may also be similar to that of motivational propensities' reasons aspects. 


\section{e. Personalities}

Results also revealed that the students prefer to speak with their friends rather than presenting in front of strangers.Another aspect that is closely related to self-confidence is personality. Students who think that they are introvert state that they tend to have a lack of confidence when they speak English. Hence, the students feel shy or less confident when they have to speak English in front of the class for example or they have to speak for the need of assignment of English lecture. Thus, these students believe that liveworksheets.com really help them to express their utterances without having to feel anxious as they do not need to speak face to face with teachers or other people. Instead, they are challenged to autonomously correct their pronunciation mistakes, as also suggested by Bukhari, et.al (2015). In contrast however, Ulin (2020) analyzed the types of personality and their relation to the achievement of EFL students' reading comprehension, and she found that there is no influence of personality types to the reading comprehension of EFL students. For this reason, it makes a clear distinction between the previous study conducted by Ulin (2020) and this study.

\section{Liveworksheets in Facilitating Students to Acquire English Language}

It has been suggested from the questionnaire's result that most of the learners who have experienced in learning L2, English language, by using liveworksheets.com agree that the platform can help them to improve their target language speaking skills. Most learners agree that the platform helps them to acquire their L2 speaking skill with different reasons. There are $45 \%$ of learners who say that the platform helps them in practicing L2 speaking skill, as they can try to answer the exercise repeatedly until they are able to answer and know the right one. This coincides with Lin (2015) opinion that SLA witnessed an ever-increasing interest in using communication technologies. The other $45 \%$ learners say that the platform can improve their L2 speaking skill because the platform can detect the pronunciations errors. As suggested by Saito (2007), obvious pronunciation prevents the learners from successful communication with L1 speakers even those with a large vocabulary and grammar. Thus, the learners can try to autonomously correct their own mistakes. Meanwhile, the rest of learners say that the platform helps them to improve their speaking skill because the platform increases their motivation in practicing L2 speaking skill. In conclusion, the platform can improve the learners L2 speaking skill because it can be used to practice L2 speaking skills even though there are no real friends to talk to. Later, the platform can detect the pronunciation errors even it motivates the learners to learn the target language. 


\section{CONCLUSION AND SUGGESTION}

\section{Conclusion}

The current study aimed at investigating student's willingness to communicate. in this study, liveworksheet.com was chosen as the instrument to measure how student are willing to communicate and acquiring language using this platform. Answering the first research question, liveworksheet.com is the platform that helps students enhancing their WTC. This online learning allows student to generate and construct their personality trait and language learning environment in acquiring their L2. Some aspects of WTC were found during the use of liveworksheet.com. Selfconfidence, the desire communicates with the specific person, and personality found as the dominant aspect affected student's willingness to communicate.

In this case, the fear of making mistake is not found in this study because using liveworksheet.com, they experienced the enjoy learning to speak without any audiences. Absolutely, self - confidence increases and reduce the anxiety while speaking. Moreover, in acquiring L2, liveworksheet.com greatly helps students to acquire language because this platform directly gives the feedback while students pronounce well or not. Therefore, it motivates students to practice more after knowing their mistake. In short, not only the self confidence is affected by liveworksheets, but also the willingness to communicate is influenced by that online learning platform.

Deals with the second research question, all aspects of WTC were found to be affective in promoting students' communication skills and eventually acquire their second language despite the fact that one factor may contribute more than others. However, As assessed by the participants of this study, Self-confidence as motivational propensities from layer IV and communicative competence as affective cognitive context from layer $\mathrm{V}$ made a different significant contribution as the dominant aspect constructing student to acquire their second or foreign language, then followed by situated antecedent aspects from layer III and willingness to communicate as behavioral intention and personality from layer VI. However, the highlight point of this research is not all WTC aspects assisted as the factor influencing student's willingness to communicate, such as intergroup attitude in layer $\mathrm{V}$ and intergroup climate in layer VI. The findings surprisingly differ from other previous studies.

Some motivation factors also were driven to support reducing student's anxiety and increasing self-confidence, such as having good readiness on their language skills through their English proficiency, might help them to have more self-confidence. On the other hand, the familiar topic about a certain issue for the discussion motivates them to use English accurately. This fact was proven by the student when answering the given question in liveworksheets.com, they answered enthusiastically in correlation to the familiar topics. In addition to this factor, the foreign learners still hesitate to 
JEASP

Journal of English for Academic and Specific Purposes

Volume 4 Number 1, June, 2021

communicate immediately to the interlocutor. Therefore, from the result students were very confident with their English-speaking skills without having to worry about others' opinion or if others are laughing at them when they created a mistake during speaking, because liveworkseets.com offers them a chance to learn autonomously about how to accurately produce the targeted language in speaking.

To sum up, many factors affect student to be willing to communicate, it can be from the outside or the inside aspect of the student's itself. The researchers believe that online learning platform such as liveworkseets.com provide the similar effective learning such as classroom learning. By providing the appropriate topic, having learning situation effectively, knowing the goal orientation of learning, and having good preparation might help students to communicate well and increase the desire to communicate. What is more important is that several WTC aspects attributed to the communication apprehension could be improved by self-perceive competence by improving self-confidence, communicative competence and performing the good personality.

\section{Suggestion}

Within the line of this research, to get a broader context the further research on WTC should concern to the Indonesian culture, their proficiency with different gender and the social background of the students. Comparing student's actual WTC behavior in an L2 classroom and online classroom could give the opportunity for new research studies. Future studies also could take account on examining WTC aspect through different gender in order to see the personality trait toward male and female students. Moreover, future research also must explore the relation between the different WTC in English specific purposes in the different culture such as observing the foreign learner's way of communication with Indonesian learners or examining the Indonesian teacher's way of creating student's desire to communicate.

\section{REFERENCES}

Bukhari, S.F., Cheng, X., and Khan, S.A. (2015). Willingness to Communicate in English as a Second Language: A Case Study of Pakistani Undergraduates. Journal of Education and Practice, 6(29). https:// files.eric.ed.gov/fulltext/EJ1081256.pdf

Canale, M., \& Swain M. (1980). Theoretical based of communicative approaches to second language teaching and testing. Applied Linguistics, 1(1) 1-47.

Cao, Y. K. (2014). A Sociocognitive Perspective on Second Language Classroom Willingness to Communicate. TESOL Quarterly, 48(4), 789-814. DOI:10.1002/tesq.155

Ghanbarpour, M. (2016). Willingness to communicate, linguistic self-confidence, and language- use 


\section{JEASP}

Journal of English for Academic and Specific Purposes

Volume 4 Number 1, June, 2021

anxiety: The iranian EFL context. Theory and Practice in Language Studies, 6(12), 2265. DOI:10.17507/tpls.0612.05

Ghani, M., \& Azhar, S. W. (2017). Effect of motivation, willingness to communicate (WTC), self perceived communicative competence (SPCC) and L2 anxiety on the frequency of use of english as L2. Journal of Educational Research, 20(1), 157.

Holliday, A. (2015). Qualitative research and analysis. In Paltridge, B \&Phakiti, A. (Eds). Research method in applied linguistics (pp.49-62). London, UK: Bloomsbury.

Ivankova, N.V., Greer, J.L. (2015). Mixed methods research and analysis. In Paltridge, B., \& Phakiti, A. (Eds). Research method in applied linguistics (pp.63-82). London, UK: Bloomsbury.

MacIntyre, P. D., Clément, R., Dörnyei, Z., \& Noels, K. A. (1998). Conceptualizing willingness to communicate in a L2: A situational model of L2 confidence and affiliation. The Modern Language Journal, 82(4), 545-562. DOI:10.1111/j.1540-4781.1998.tb05543.x

Pawlak, M., \& Mystkowska-Wiertelak, A. (2015). Investigating the dynamic nature of L2 willingness to communicate. System, 50, 1-9. DOI:10.1016/j.system.2015.02.001

Phakiti, A. (2015). Quantitative research and analysis. In Paltridge, B., \& Phakiti, A.(Eds). Research method in applied linguistics (pp.28-48). London, UK: Bloomsbury.

Pramita, G.A.P. (2012). The Contribution of Self-esteem and Language Learning Strategies to the Students' English Proficiency for Second Year Students of SMA Negeri 7 Denpasar. Published article. Buleleng: Universitas Pendidikan Ganesha. https://media.neliti.com/media/publications/206823none.pdf

Tavakoli, E., \& Davoudi, M. (2017). Willingness to communicate orally: The case of iranian EFL learners. Journal of Psycholinguistic Research, 46(6), 1509-1527. DOI:10.1007/s10936-017-9504-0

Ulin, S. (2020). The Link between Personality Types and Reading Comprehension Achievement of the Eleventh Grade Senior High School Students. Jurnal Pendidikan dan Pengajaran, 7(1). http://jurnal.radenfatah.ac.id/index.php/edukasi/article/download/5698/3057/

Saito, K. (2007). The Influence of Explicit Phonetic Instruction on Pronunciation in EFL Settings: The Case of English Vowels and Japanese Learners of English. The Linguistics Journal, 3(3), 1640.

Wood, D. (2016). Willingness to Communicate and Second Language Speech Fluency: An Idiodynamic Investigation. System, 60,11-28. DOI:10.1016/j.system.2016.05.003

Yashima, T. (2002). Willingness to Communicate in a Second Language: The Japanese EFL Context. Modern Language Journal, 86(1), 54-66. https://www.researchgate.net/publication/227534388_Willingness_to_Communicate_in_a_S econd_Language_The_Japanese_EFL_Context

Zarrinabadi, N., \& Tanbakooei, N. (2016). Willingness to communicate: Rise, development, and some future directions: Willingness to communicate. Language and Linguistics Compass, 10(1), 30-45. DOI:10.1111/lnc3.1217 